\title{
Relationship between Job Satisfaction, Pay, Affective Commitment and Turnover Intention among Registered Nurses in Nigeria
}

\author{
Benjamin Akinyemi ${ }^{1,2}$, Babu George ${ }^{3} \&$ Alice Ogundele $^{4}$ \\ ${ }^{1}$ Department of Management, Swiss Management Center University, Switzerland \\ ${ }^{2}$ Department of Management, Central University of Nicaragua, Managua, Nicaragua \\ ${ }^{3}$ Christian Brothers University, Mamphis, Tennessee, USA \\ ${ }^{4}$ Ondo State Ministry of Health, Akure, Nigeria \\ Correspondence: Benjamin Akinyemi, Bahnhofstrasse 20, 6300 Zug, Switzerland. E-mail: \\ akinyemi.ben@gmail.com
}

Received: November 21, 2021 Accepted: December 14, 2021 Online Published: January 4, 2022

doi:10.5539/gjhs.v14n2p37

URL: https://doi.org/10.5539/gjhs.v14n2p37

\begin{abstract}
This study aims to examine the relationship between job satisfaction, pay, affective commitment, and turnover intentions of public hospitals-based Registered Nurses in Ondo State, Nigeria. Using the quantitative, cross-sectional survey design, data from 220 Registered Nurses were analysed. Results indicate that pay and job satisfaction have significant positive relationship with nurses' affective commitment; pay has significant positive relationship with their job satisfaction but pay, job satisfaction and affective commitment have negative relationship with turnover intentions. Job satisfaction is of critical importance in gaining nurses' affective commitment and enhancing retention. Pay is often considered as a hygiene factor in theories of motivation meaning, even though pay decreases might cause dissatisfaction, pay increases would not increase satisfaction. This does not appear to be the case in Nigeria. These findings have implications for health human resource management in general and the management of nursing staff in the public hospitals of Ondo State, Nigeria in particular.
\end{abstract}

Keywords: affective commitment, pay satisfaction, registered nurses, retention, job satisfaction

\section{Introduction}

Nurses are the largest group of health workforce and play significant role in every country's healthcare system because of their specialized skills and the indispensable support and service they render (Bolina, Bomfim, \& Lopes-Júnior, 2020; Reynolds, 2020). They are critical to meeting the global, national and local targets for health and health related Sustainable Development Goals (Tangcharoensathien, Mills \& Palu, 2015). Nurses care for peoples' health needs throughout their entire life cycle, play very critical roles in building the resilience of communities to respond to diverse health conditions and to achieve global objectives such as universal health coverage and the Sustainable Development Goals (Buchan \& Aiken, 2008). Nurses are a major pillar in any country's healthcare system because of their relatively huge number when compared to other skilled health professionals. Without their significant contributions attaining healthcare services delivery goals is not feasible (Bradby, 2014). Salami, Dada, and Adelakun (2016) suggested that nurses' shortage is detrimental to a country's health performance (as cited in Mavodza, 2017).

Globally, nurses account for about $50 \%$ of the global health workers but are in short supply (Haddad, Annamaraju, $\&$ Toney-Butler, 2020). This situation is more critical in 57 countries which have deficit of 2.4 million doctors and nurses. While the Americas has 24.8 health workers per 1000 population, Africa has only 2.4 health workers per 1000 population. To meet the SDGs, 4.5 health workers per 1000 population is required but the African Region had an average of 1.30 in 2015 and the region has the most severe health workforce shortage estimated to reach 6.1 million by 2030 (WHO Africa, 2017, August). Continued shortage of health workforce will hamper government efforts to scale health interventions for achieving health related development targets (Liu, Goryakin, Maeda, Bruckner, \& Scheffler, 2017; Tangcharoensathien, Mills, \& Palu, 2015).

In sub-Saharan Africa (SSA), they form a major part of the health workforce constituting between 45-60 percent of the entire health workforce and providing a broad range of services (Asegid, Belachew, \& Yiman, 2014). 
However, along with the South East Asia, the SSA have been experiencing critical needs-based shortages of nurses and midwives (WHO, 2018). The acute shortage of health workforce in SSA and the deficit amounts to 2.4 million doctors and nurses (Naicker, Eastwood, Plange-Rhule, \& Tutt, 2011). Specifically, SSA has 11 nursing/midwifery personnel per 10,000 population, while the Americas have 49 nursing/midwifery personnel per 10,000 and Europe, 78 nursing/midwifery personnel per 10,000. The high-income regions of the world have 87 nurses/midwifery personnel per 10,000 but there are only 11 nurses/ midwifery personnel per 10,000 in low-income regions (Naicker, Eastwood, Plange-Rhule, \& Tutt, 2010). The persistent shortage of skilled health professionals will hamper government efforts to scale health interventions that are essential for achieving health related development targets (Liu, Goryakin, Maeda, Bruckner, \& Scheffler, 2017).

Nigeria, which has one of the largest stocks of skilled health workers in SSA, has low densities of nurses, midwives and doctors $(1.95$ per 1,000) for effective delivery of essential health services (WHO, 2019). This situation, according to Salami, et al. (2016), is detrimental to a country's health performance (in Mavodza, 2017) and to achieving its Universal Health Coverage. The health situation in Nigeria remains dire with unacceptably high health outcome indicators and uncertainty about achieving the SDGs (WHO, 2018) even as it is reported that the country did not meet any of the Millenium Development Goals (Durokifa \& Abdul-Wasi, 2016; Oleribe \& Taylor-Robinson, 2016). Nigeria's health sector human resource challenges have assumed a systemic and critical dimension as it faces healthcare workforce shortage in quantity, quality, right mix and an uneven distribution that result in poor healthcare delivery. Persistent and prolonged industrial health workforce crises put undue pressure on healthcare service delivery (Oleribe, Udofia, Oladipo, Ishola, \& Taylor-Robinson, 2018; Oleribe \& Taylor-Robinson, 2016; Oleribe, Ezieme, Oladipo, Akinola, Udofia, \& Taylor-Robinson, 2016). For instance, over a 36-month period (2013-2015), more than 10 different healthcare workers' strikes were recorded in Nigeria (Oleribe et al., 2016). This situation is usually linked to unfavorable human resource management policies and practices which negatively affect healthcare professionals' behavior and attitude. It is essential to examine the relationships among nurses' job satisfaction, pay, affective commitment and turnover intention (Yeager \& Wisniewski, 2017; Goh \& Lopez, 2016).

Ondo State, located in Southwest Nigeria, is one of the 36 states in Nigeria with a total population of 3,440,024 (National Population Commission 2006). There are 1,102 nurses working in 4 State Specialist and 14 General Hospitals. Also, a total of 299 nurses work at the 575 Primary Health Care Centres in the 18 Local Governments of the State (Ondo State Ministry of Health, 2018). The Federal Medical Centre, Owo (FMC) has 320 nurses instead of 600 nurses that are needed to cover all the shifts conveniently (Ondo State Ministry of Health, 2018). Hence, the total number of nurses in all the 3 tiers of Government is 1,621 serving a total population of 3,440,044. This indicates that there is a severe shortage of Nurses in Ondo State. The persistent skilled healthcare professionals' (SHPs) crisis in Nigeria has reached quite disturbing proportions thus putting healthcare services under serious pressure. Conditions of service, including remuneration, are generally understood to be a major part of SHPs' grievances which often leads to industrial actions.

\section{Literature Review}

\subsection{Affective Commitment}

Affective commitment has been identified as the core essence of organizational commitment based on these three significant findings: "(a) affective commitment seems to serve as a historical and theoretical base for organizational commitment theories, (b) affective commitment may more strongly influence work behaviors than other components or proposed forms of commitment, and (c) affective commitment may be reasonably considered a core essence of organizational commitment" (Mercurio, 2015, p. 403). A core essence, in this context, is defined as "an enduring, indispensable, and central characteristic of the organizational commitment construct that distinguishes it from other constructs" (Mercurio, 2015, p. 393).

According to Allen and Meyer (1991), affective commitment is “...the employee's emotional attachment to, identification with, and involvement in the organization. It describes one's affective orientation towards the organization. Employees with a strong affective commitment continue employment with the organization because they want to do so" (p. 67). Affective commitment to an organization "emphasizes an emotional attachment, with a volitional desire for involvement, and alignment of individual and organizational values. This emotional attachment is positive in nature and appears to derive from conditions such as fairness, support from senior staff and colleagues, as well as value for individual worth and contributions" (Staples \& Barlett, 2003). In affective commitment, an employee is psychological bonded to, associated and intentionally staying with the organization. Having developed an emotional attachment to the organization, the employee is aligned with organizational goals and gives support for such goals to be achieved (Allen \& Meyer, 1990). 


\subsection{Pay Satisfaction}

Equitable and commensurate pay is part of employees' expectations at work. Pay is at the base of Maslow's hierarchy of needs (Maslow, 1943) and part of hygiene factors, classified as dissatisfiers, in Herzberg's two-factor theory (Herzberg, Mausner, \& Snyderman, 1959). According to Maslow, when organizations fulfill employees' psychological needs by offering equitable, competitive and commensurate pay and benefits, employees move to higher levels of needs satisfaction of safety or job security to which organizations respond by putting in place relevant organizational policies and practices. According to Herzberg, et al. (1959), hygiene factors cause job dissatisfaction while motivators enhance job satisfaction and though each of these two factors is separate and distinct from each other they are connected. Hygiene factors, such as, policies, supervision relationships, work conditions, remuneration, salary and security are present within the job environment but motivators which include achievement, recognition, the work itself, responsibility, advancement and growth, are found in (or intrinsic to) the job. Hackman and Lawler (1971) suggest that pay satisfaction influences employees' job satisfaction. Pay satisfaction shows that employees' psychological needs are fulfilled (Kanfer, 1990) and this triggers attitudinal and behavioral responses.

Employers and employees alike are primarily concerned about pay satisfaction (Singh \& Loncar, 2010) in view of its potential impact on employment relations, performance and retention. In a causal model for turnover developed by Price and Mueller (1981), seven job satisfaction factors are identified as indirect determinants and influencers of turnover. These are: routinization, participation, instrumental communication, integration, pay, distributive justice and promotional opportunity. This suggests that pay influences job satisfaction and employee turnover. In view of the fact that nurses are generally in high demand and in short supply, retention strategies should include satisfactory pay and benefits. Since nursing shortage is a persistent challenge, for available nurses to be committed, satisfied and retained, their organizations would need to ensure that pay and benefits are perceived by nurses to be competitive, equitable, and commensurate.

\subsection{Job Satisfaction}

Scholars have defined the concept of job satisfaction in various ways. However, the definition of job satisfaction by Locke (1976) as "a pleasurable or positive emotional state resulting from the appraisal of one's job or job experiences" (p. 1304) is one of the most widely used in organizational research. Spector (1997) describes job satisfaction as "how people feel about their jobs and different aspects of their jobs. It is the extent to which people like (satisfaction) or dislike (dissatisfaction) their jobs" (p. 2). According to Spector (1997), there are 14 facets of job satisfaction, viz: Appreciation, Communication, Coworkers, Fringe benefits, Job conditions, Nature of the work, Organization, Personal growth, Policies and procedures, Promotion opportunities, Recognition, Security, and Supervision.

Others have taken a multi-dimensional approach to understanding the concept arguing that as an employee's psychological response to job situation it consists of three components such as cognitive (evaluative), affective (or emotional), and behavior components (Hulin \& Judge, 2003; Eagley \& Chaiken, 1993). This psychological response (cognitive, affective and behavioral) is influenced by organizational factors (policies and practices) that include salaries and benefits, work environment, culture and climate, relationships, working conditions, etc. (Chevalier, Fouquereau, Benichoux, \& Colombat, 2018; Yilmazel, 2013; Krueger, Brazil, Lohfeld, Edward, Lewis \& Tjam, 2002). Bernstein and Nash (2008) state that employees' emotional feelings manifest in the form of happiness, anxiety, boredom and excitement while the behavioral responses include arriving early, working late, tardiness and absenteeism. Invariably, employees' level of satisfaction at work depends on the extent they feel their needs are met (Al Maqbali, 2015). Nurses' dissatisfaction is associated with staffing, resources, salaries and workplace safety which management should address in order to enhance nurses' retention (Tshitangano, 2013).

The peculiarity of the nursing profession demands that management puts high premium of nurses' job satisfaction. By nature, the profession is labor-intensive, physically and psychologically demanding, emotionally draining, work environment is chaotic and unpredictable and, often, respect is lacking from administrators and physicians (Saber, 2014). Perennial nursing shortage also puts maximum pressure on available nursing staff which often result in overwork, stress, errors, psychosomatic problems and burnout and are capable of further shrinking the workforce (MacPhee, Dahinten \& Havaei, 2017; Bahram, Hasan, Mohammad, Hasan, \& Alireza, 2015).

\subsection{Nursing Turnover}

According to the Charttered Institute of Personnel Development (CIPD, 2021), employee turnover is "the proportion of employees who leave an organisation over a set period (often on a year-on-year basis), expressed as a percentage of total workforce numbers." It is an employee's voluntary or involuntary permanent exit from an 
employing organization (Robbins, Judge, Odendaal, \& Roodt, 2016). According to Mobley (1981), turnover is the “... cessation of membership in an organization by an individual who received monetary compensation from the organization" (in Greyling \&Stanz, 2010, p. 2). Voluntary turnover is an employee's voluntary withdrawal of membership from an organization (Morrell et al., 2001) while the "...movement across the membership boundary of an organization, which is not initiated by the employee" (Price, 1977, p. 9) but by the employer due to factors that include retirement, incapacity, misconduct and poor performance is known as involuntary turnover (Matlala and Westhuizen, 2012). Global voluntary turnover rate was $9.6 \%$ in 2016 and stood at $7.1 \%$ for Europe (Gutmann, 2016, June 23). Employees voluntarily leave organizations for a variety of reasons, including low satisfaction with their jobs, low satisfaction with their employer, limited promotion and growth opportunities, a better opportunity elsewhere, or disapproval of organizational changes or restructuring. Actual turnover is expected to increase as the intention increases. The measurement of turnover intention can determine the likelihood of the staff leaving the organization. This helps to determine how one can find opportunities to reduce the overall turnover.

Although turnover intention is in the realm of thoughts, reasoning and part of the decision process, it is nevertheless very significant in relation to actual turnover (Firth, Mellor, Moore, \& Loquet, 2004; Hom \& Griffeth, 1995). It is the desire of an employee to voluntarily discontinue or leave their present employment relationship with current employing organization (Yang, Tsai, \& Tsai, 2014). Turnover intention is defined as the reflection of "the (subjective) probability that an individual will change his or her job within a certain time period" (Sousa-Poza \& Henneberger, 2002, p. 1). An intention is a statement about a specific behavior of interest. It is the probability that an employee will leave for another organization within a certain time period, thus leading to actual turnover. It is the employee's thoughts or plan to voluntary quit an organization or the profession (Lambert, Cluse-Tolar, Pasupuleti, Prior, \& Allen, 2012 cited in Hayes, 2015) and is understood to be a strong predictor of actual turnover (Cohen, Blake, \& Goodman, 2015; Garner \& Hunter, 2014).

Strafford (2016, March 16) reports that turnover rate in healthcare is the highest with just a few points behind Banking (13.3\%), and Hospitality (20.2\%). Among healthcare professionals, nurses remain the most susceptible to quick turnovers. Voluntary nurses' turnover is the number of voluntary uncontrolled separations during the month for unit nurses and Advanced Practice Nurses (APNs) divided by the number of unit employees (full-time plus part-time) on the last day of the month for nurses and APNs, multiplied by 100 to get percentage (Institute for Healthcare Improvement, 2019). Nurses' turnover is driven by factors such as role overload, demanding schedule, absence of reward or recognition for achievements, lack of value or respect for contributions and job performance, lack of opportunities for promotion, career development or advancement, poor work environment and culture, management insensitivity (Tinehealth, 2017).

Nursing turnover is very costly and has huge impact on hospitals' profit margin (Cimiotti, Aiken, Sloane, \& Wu, 2013). According to the 2016 National Healthcare Retention and Nurses Staffing Report puts the average cost of a nurse turnover as ranging from $\$ 37,700$ to $\$ 58,400$ and Hospitals can lose $\$ 5.2$ million to $\$ 8.1$ million annually as a result. It is reported to have negative impact on patients, nurses, doctors, and hospitals (Dewanto \& Wardhani, 2018). It is estimated that in the Africa Region, the total cost of educating one nurse from primary school to college of health sciences is US $\$ 43,180$; for every nurse that emigrates, a country loses about US $\$ 1,213,463$ returns from investment (Kirigia, Gbary, Nyoni, Seddoh, \& Muthuri, 2006). More insidious effect of nursing turnover is increased fatigue experienced by remaining undermanned which results in decreased team morale and impacts on-floor performance adversely (Strafford, 2016).

\section{Methodology}

Using cross-sectional survey design, a stratified sample of Nurses ( $\mathrm{N}=220)$ from six public hospitals in Ondo State of Nigeria was obtained. A self-administered questionnaire comprising of five sections was used to obtain data from respondents. Data analysis was conducted using the exploratory factor analysis, regression analysis, Pearson's correlation and descriptive statistics.

\subsection{Hypotheses}

The following hypotheses were formulated for statistical testing in the study:

1) Registered Nurses' perceptions of job satisfaction will have no significant positive influence on affective commitment but will have a significant positive influence on turnover intention.

2) Registered Nurses' perceptions of pay satisfaction will have no significant positive influence on job satisfaction and affective commitment but will have a significant positive influence on turnover intention.

3) Registered Nurses' perceptions of affective commitment will have no significant negative influence on turnover intention. 


\subsection{Instruments}

The study used four validated instruments. The instruments form a structured 18-item survey questionnaire with nine (5) sections and comprised of overall job satisfaction (3 items), pay satisfaction (3 items), affective commitment (4 items), turnover intention (3 items) and demographic variables (5 items). Overall job satisfaction (OJS), according to Spector (as cited in O'Connor, 2018, p.3), is an employee's overall feeling about the different aspects of a job. This 3-item scale was developed by Cammann, Fichman, Jenkins, and Klesh (1983, as cited in Fields, 2013). Scale items for this construct were: 1 . Generally speaking, I am very satisfied with this job; 2 . I am generally satisfied with the kind of work I do in this job; 3 . Most nurses in this hospital are very satisfied with the job. Registered Nurses' perceived satisfaction with pay (PS) was measured with a 3-item scale developed by Tang, Luna-Arocas and Lara (2020). This instrument addresses satisfaction with pay, appropriateness of pay and how their pay compared with colleagues in similar jobs. The scale items were: 1 . I am satisfied with my pay; 2 . The pay I receive is appropriate for the work that I do; 3 . My pay is high in comparison with my colleagues' pay for doing a similar job.

Luna-Arocas and Lara (2020) stated that in the scientific literature, affective (emotional and attitudinal) organizational commitment is the most widely supported component of Meyer and Allen's (as cited in Allen, 2016) three-dimensional organizational commitment model. This construct will be measured with four items adapted from Meyer and Allen's (1997) six original affective organizational commitment component scale. The following items were used: 1. I would recommend my hospital to my friends as a great place to work; 2. I am proud to tell others that I work for this hospital; 3. My hospital inspires me to do my best work, and; 4. I am pleased with my decision to work for this hospital. Turnover intention (TI) is an employee's intention to voluntarily leave an organization (Hongvichit, 2015). Nurses' perception of their TI was measured using a three-item scale adapted from Camman, Fichman, Jenkins and Klesh (as cited in O'Connor, 2018). The items were: 1. I often think of leaving this hospital; 2. If I may choose again, I will choose to work for the current hospital, and; 3 . It is very possible that I will look for a new job within the next year.

\subsection{Sample and Sampling Technique}

This study focuses on full-time, permanent Registered Nurses with not less than 12 months of experience, working at unionized public hospitals in Ondo State of Nigeria. A sample of 250 Registered Nurses were selected through a multi-stage sampling technique using Krejcie and Morgan (1970) sampling formula. Before data collection, the Ondo State Health Research Ethics Committee (OSHREC) granted ethics approval to the researchers (AD.4693 Vol. 11/17). Prior to data collection exercise, respondents' consent was sought in writing and the purpose of the research was duly communicated to them. They were assured of anonymity and confidentiality. The study participants were selected from 6 public hospitals which was determined via purposive sampling technique. Since the Registered Nurses were based in hospital units, the units were selected using purposive sampling technique and the respondents were selected using convenience sampling. A total of 250 completed questionnaires were retrieved but only 220 questionnaires were considered useful for analysis. This gives a response rate of $90 \%$ percent and was deemed to be acceptable (Christley, 2016).

\section{Data Analysis and Results}

The quantitative data analysis such as Spearman's correlation coefficient, factor analysis and regression analysis were performed to determine the relationship among the variables. Descriptive analysis was conducted on demographic variables, validity and reliability of scales for variables were determined using the Cronbach Alpha. The results of descriptive statistical analysis, reliability and validity of scales, factor analysis based on the Bartlett test outputs, correlation and regression analyses are presented in this section.

\subsection{Demographic Statistics}

The composition of the 220 respondents in this study show that $89 \%$ were female $(\mathrm{n}=193)$, whereas $11 \%$ were male $(\mathrm{n}=23)$ indicating that the nursing profession in Ondo State of Nigeria is female dominated. Fifty-one percent of the respondents were 35 years old and below while 58 respondents $(27 \%)$ were between $36-45$ years of age, $19 \%$ or 40 respondents were between $46-55$ years and only $4 \%$ (9) respondents were above 55 years old indicating that most of the nurses were below the age of 45 . Most of the nurses ( 113 or $60 \%)$ have put in 10 years of service or lower whereas a total number of $86(40 \%)$ respondents have worked for more than 10 years. The majority of the nurses (148 or 68\%) earned a monthly income of N150 000 or below while 68 or $32 \%$ of the respondents earned above N150 000. Eleven (5\%) of the respondents held midwifery diploma (trained exclusively in midwifery), 44 respondents $(20 \%)$ had a nursing diploma, 69 respondents $(32 \%)$ held nursing-midwifery diploma, 87 respondents $(40 \%)$ hold university degrees (B.Sc./M.Sc.) in nursing were either nurses or midwives, 
one $(0.5 \%)$ respondent had a $\mathrm{PhD}$ degree in nursing and four $(2 \%)$ possessed other nursing qualifications.

\subsection{Reliability of Scales}

The coefficient alpha for each of the four variables, ranged from .68 to .90 (job satisfaction .90, pay satisfaction .84 , affective commitment .82 and turnover intention .68 ) exceeding the .60 acceptable standard for reliability (Hair, Black, Babin, Anderson, \& Tatham, 2018) and signifying their internal consistency. Given the reliability statistics (Cronbach's Alpha) results for each of the four constructs $(.68-.90)$, it was concluded that each of the scales met the reliability criteria (for internal consistency) to be included in the study (Hair et al., 2018).

\subsection{Explorators Factor Analysis}

Exploratory factor analysis (table 1) using the principal components analysis method and Varimax rotation was applied in order to identify the underlying dimensions and simplify the structure and interpretation was based on the variable with the highest loading on each principal component (PC) (Barik, Bramha, Behera, Bastia, Cooper \& Rath (2019). This statistical method (PCA), with minimal information loss, can reduce a large number of correlated variables into a smaller number of uncorrelated components (Silva-Flores, Perez-Verdin. \& Wehenkel (2014). The aim is to understand how variables contributed to turnover intention levels on the basis of their loadings in the PCs. A minimum cut-off of 0.50 was applied on the factor loadings (Hair et al. 2014). With the Bartlett test output (significance at 0.000 , Chi-square $\left(\chi^{2}\right)=1243.813$, Kaiser-Meyer-Olkin $($ KMO $)=0.851$ ), we infer that the dataset used is not an identity matrix and suitable for factor analysis.

Table 1. Exploratory Factor Analysis

\begin{tabular}{|c|c|c|c|c|c|c|c|c|c|}
\hline \multirow[b]{2}{*}{ Factor } & \multirow[b]{2}{*}{ Label } & \multicolumn{4}{|c|}{ Initial Eigenvalues } & \multicolumn{3}{|c|}{$\begin{array}{l}\text { Rotated } \\
\text { component matrix }\end{array}$} & \multirow[t]{2}{*}{ Description } \\
\hline & & $\begin{array}{l}\text { Total } \\
\text { (Total }\end{array}$ & $\begin{array}{l}\% \\
\text { Variance } \\
\text { variance ex }\end{array}$ & $\begin{array}{l}\text { Cumula- } \\
\text { tive } \% \\
\text { plained) }\end{array}$ & Item & $\begin{array}{l}\text { PC1 } \\
\text { Comp }\end{array}$ & PC2 & PC3 & \\
\hline 1 & $\begin{array}{l}\text { Job satisfaction } \\
\text { (JS) }\end{array}$ & 4.931 & 49.307 & 49.307 & $\mathrm{JS}_{2}$ & 0.886 & & & $\begin{array}{l}\text { General satisfaction with the } \\
\text { kind of work being done. }\end{array}$ \\
\hline 2 & $\begin{array}{l}\text { Affective } \\
\text { commitment (AC) }\end{array}$ & 1.617 & 16.168 & 65.475 & $\mathrm{JS}_{1}$ & 0.844 & 0.313 & & Nurse is satisfied with the job. \\
\hline \multirow[t]{8}{*}{3} & $\begin{array}{l}\text { Pay satisfaction } \\
\text { (PS) }\end{array}$ & 1.005 & 10.052 & 75.527 & $\mathrm{JS}_{3}$ & 0.799 & & & $\begin{array}{l}\text { Most Nurses in this hospital are } \\
\text { very satisfied with the job. }\end{array}$ \\
\hline & & & & & $\mathrm{AC}_{3}$ & & 0.822 & & $\begin{array}{l}\text { Hospital management inspires } \\
\text { nurses to do their best work. }\end{array}$ \\
\hline & & & & & $\mathrm{AC}_{2}$ & 0.367 & 0.767 & & $\begin{array}{l}\text { Nurses are proud to be } \\
\text { associated with their workplace. }\end{array}$ \\
\hline & & & & & $\mathrm{AC}_{4}$ & 0.392 & 0.707 & & $\begin{array}{l}\text { Nurse is pleased with the } \\
\text { decision to work for the } \\
\text { hospital. }\end{array}$ \\
\hline & & & & & $\mathrm{AC}_{1}$ & & 0.706 & 0.338 & $\begin{array}{l}\text { Hospital is highly recommended } \\
\text { as a great place to work. }\end{array}$ \\
\hline & & & & & $\mathrm{PS}_{2}$ & & & 0.899 & $\begin{array}{l}\text { Pay is appropriate for the work } \\
\text { done. }\end{array}$ \\
\hline & & & & & $\mathrm{PS}_{3}$ & & & 0.836 & $\begin{array}{l}\text { Higher pay in comparison to } \\
\text { similar jobs. }\end{array}$ \\
\hline & & & & & $\mathrm{PS}_{1}$ & & & 0.797 & Nurses' satisfaction with pay. \\
\hline
\end{tabular}

From the analysis, the influence of variables on nurses' turnover intention in Ondo state can be inferred (Table 3). On the basis of the rotated component matrix, three PCs were extracted explaining $76 \%$ of the total variance in turnover intention. PC1 explained about $50 \%$ of the total variance with the highest positive loadings from nurses' job satisfaction. PC2 explained $16 \%$ of the variance and is labelled employee's affective commitment to the 
hospital where they work. PC3 which explained $10 \%$, has highest positive loadings from pay satisfaction and is so labelled. The remaining $24 \%$ influence on Turnover Intention that is unaccounted for by JS, AC and PS are extraneous to this study. Therefore, further empirical studies are required to examine the impact of other variables on Nurses' turnover intention in Ondo State of Nigeria.

\subsection{Correlation Analysis}

There was a need to establish the influence of pay satisfaction on job satisfaction, affective commitment and turnover intention in line with formulated hypotheses. It was also necessary to determine the influence of job satisfaction on affective commitment and turnover intention and the influence of affective commitment on turnover intention (Tables 2 and 3 ).

Table 2. Correlation Analysis

\begin{tabular}{lllll}
\hline Variables & AC & JS & PS & TI \\
\hline Affective Commitment & 1 & - & - & - \\
Job Satisfaction & $0.511^{* *}$ & 1 & - & - \\
Pay Satisfaction & $0.363^{* *}$ & $0.346^{* *}$ & 1 & - \\
Turnover Intention & $-0.355^{* *}$ & $-0.457^{* *}$ & $-0.227^{* *}$ & 1 \\
\hline
\end{tabular}

Note. ${ }^{*}$ Correlation is significant at the 0.01 level (2-tailed).

Results of correlation analysis (Table 2) is clearly shown in Figure 1 below. Registered Nurses' perception of job satisfaction has a significant positive influence on affective commitment but a significant negative influence on turnover intention; their perception of pay satisfaction has a significant positive influence on job satisfaction and affective commitment but a significant negative influence on turnover intention and their perception of affective commitment has a significant negative influence on turnover intention.

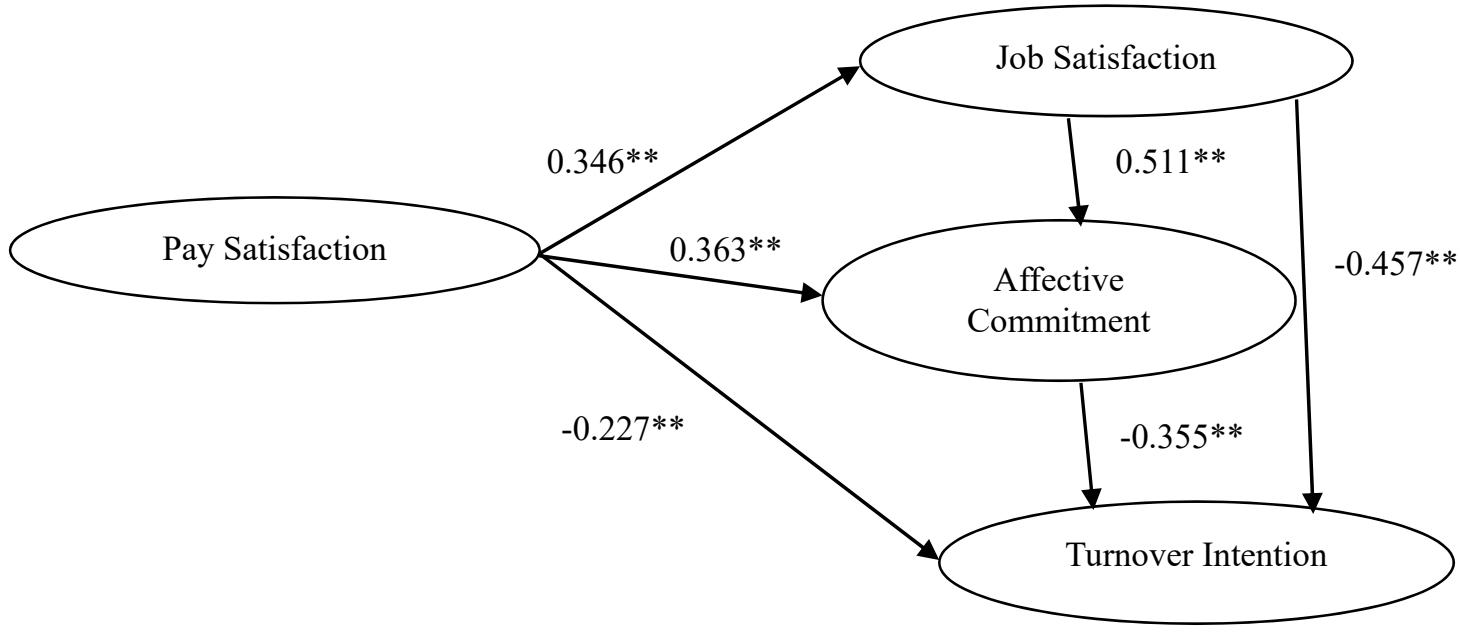

Figure 1. Results of Correlation Analysis

\subsection{Regression Analysis}

Not to connote causality, regression analysis was conducted as it enables modelling the effect of predictor factors on an outcome variable (Polit \& Beck, 2014). The three work-related factors were used as independent variables and nurses' turnover intention as dependent variable. With the large sample size used in this study, normality testing was considered unnecessary (Schmidt \& Finan, 2018) and the data as suitable for regression analysis since none of the correlation values is larger than $r>0.9$ (Mafini \& Dlodlo, 2014). Results of the effects pay satisfaction, job satisfaction and affective commitment have on nurses' intention to leave, pay satisfaction on job satisfaction as well as the effects of pay satisfaction and job satisfaction on nurses' affective commitment are shown in Table 3. The results indicate that pay satisfaction and overall job satisfaction had significant positive relationship with nurses' affective commitment $\left(r=0.594 ; r^{2}=0.353 ; p<0.05\right)$ to their hospitals. The influence of overall job 
satisfaction on affective commitment among the RNs $(\beta=0.163 ; p<0.007)$ is stronger than the effect of pay satisfaction on their affective commitment $(\beta=0.511 ; p<0.0005)$ and these are all statistically significant Multicollinearity is not a serious issue with the tolerance and VIF values all greater than 0.05 and less than five (Thompson, Kim, Aloe, \& Becker, 2017).

Table 3. Regression Analysis

\begin{tabular}{|c|c|c|c|c|c|c|c|c|}
\hline \multirow[t]{2}{*}{ No. } & \multirow{2}{*}{\multicolumn{2}{|c|}{ Hypotheses }} & \multirow[t]{2}{*}{ Variables } & \multirow[t]{2}{*}{ Beta } & \multirow[t]{2}{*}{$t$} & \multirow[t]{2}{*}{ Sig. } & \multicolumn{2}{|c|}{$\begin{array}{l}\text { Collinearity } \\
\text { statistics }\end{array}$} \\
\hline & & & & & & & Tolerance & VIF \\
\hline i. & & $\begin{array}{l}{ }^{\text {a}} \text { Pay satisfaction and Job } \\
\text { satisfaction }\end{array}$ & $\begin{array}{l}\text { Independent variable: Pay satisfaction } \\
\text { Dependent variable: Job satisfaction }\end{array}$ & 0.387 & 6.141 & $.000^{*}$ & 1.000 & 1.000 \\
\hline ii. & & $\begin{array}{l}{ }^{\mathrm{b}} \text { Pay satisfaction and } \\
\text { Affective commitment }\end{array}$ & $\begin{array}{lcc}\text { Independent } & \text { variable: Pay } & \text { satisfaction } \\
\text { Dependent } & \text { variable: } & \text { Affective } \\
\text { commitment } & & \end{array}$ & 0.163 & 2.732 & $0.007^{*}$ & 0.850 & 1.176 \\
\hline iii. & & $\begin{array}{l}{ }^{\mathrm{b}} \mathrm{Job} \text { satisfaction and } \\
\text { Affective commitment }\end{array}$ & $\begin{array}{lcr}\text { Independent } & \text { variable: Job } & \text { satisfaction } \\
\text { Dependent } & \text { variable: } & \text { Affective } \\
\text { commitment } & & \end{array}$ & 0.511 & 8.555 & $0.000 *$ & 0.850 & 1.176 \\
\hline iv. & 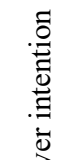 & Pay satisfaction & $\begin{array}{l}\text { Independent variable: Pay satisfaction } \\
\text { Dependent variable: Turnover intention }\end{array}$ & -0.039 & -0.578 & 0.564 & 0.821 & 1.217 \\
\hline v. & 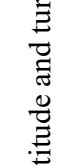 & Job satisfaction & $\begin{array}{l}\text { Independent variable: Job satisfaction } \\
\text { Dependent variable: Turnover intention }\end{array}$ & -0.331 & -4.355 & $0.000^{*}$ & 0.633 & 1.580 \\
\hline vi. & 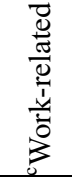 & $\begin{array}{l}\text { Affective } \\
\text { commitment }\end{array}$ & $\begin{array}{l}\text { Independent variable: } \\
\text { commitment Dependent } \\
\text { Turnover intention }\end{array}$ & -0.177 & -2.359 & $0.019 *$ & 0.647 & 1.545 \\
\hline
\end{tabular}

Note. Sig.: Significance; VIF: variance inflation factor

${ }^{a} R=0.387 ; R^{2}=0.150 ; F=37.708$

${ }^{b} R=0.594 ; R^{2}=0.353 ; F=58.073$

${ }^{c} R=0.474 ; R^{2}=0.225 ; F=20.493$

\section{Discussion and Conclusion}

Nurses' turnover behavior is a multistage process that includes attitudinal, decisional, and behavioral components and the attitudinal component includes job satisfaction (Blegen, 1993). Regression analysis results (see Table 3) show that pay satisfaction, job satisfaction and affective commitment explain about $23 \%\left(r^{2}=0.225\right)$ of the variation in nurses' turnover intention. The negative relationship between the three variables and nurses' intention to leave is confirmed $(r=0.474 ; p<0.05)$. Of these three variables, job satisfaction has a stronger effect on nurses' turnover intention $(\beta=-0.331 ; p<0.0005)$. This finding is consistent with other studies relating to nursing and other professionals.

In organizational contexts, factors influencing turnover intention have been examined by researchers. For example, A'yuninnisa and Saptoto (2015) examined the effects of pay satisfaction and affective commitment on turnover intention among employees of an automotive manufacturing company in Indonesia. Results show that turnover intention was significantly predicted by both pay satisfaction $(\gamma 1=-.19, \mathrm{p}<.05)$ and affective commitment $(\beta=$ $-.77, \mathrm{p}<.05)$. Pay is a strong determinant of employee retention as there is a significant relationship between rewards offered by a firm and employee satisfaction and engagement over a longer time duration (Iqbal, Guohao, 
\& Akhtar, 2017). Asekun (2015) reported a positive relationship between pay satisfaction and turnover intention among employees in selected business organizations in Lagos, Nigeria. Akhtar, Awan, Anwar, Saeed, Ali, \& Qurban (2016) examined the relationship between job satisfaction and remuneration and turnover intention in selected private schools in Pakistan. Their findings suggest that suggesting that turnover intention is significantly negative correlated with job satisfaction and remuneration.

Specific to nurses' turnover intention, Singh and Loncar (2010) examined the relationship among pay satisfaction, job satisfaction and turnover intention of Registered Nurses report that pay satisfaction affects turnover intent, but job satisfaction may be a more crucial variable in terms of nurses' turnover. Chien and Yick (2016) found job satisfaction to be highly negatively correlated with turnover intention among private hospital nurses in a Hong Kong private hospital. A meta-analysis of the factors that affect Registered Nurses' turnover (Pagilagan, 2017) found that the strength of the relationship between organizational commitment and anticipated turnover is moderate (-.298). Another finding (Lum, et al., 1998) suggests that pay satisfaction has both direct and indirect influence on turnover intention but job satisfaction has a direct influence while organizational commitment has the strongest and most direct impact on turnover intention of pediatric nurses. However, Proctor (2017) reports that competitive pay and bonuses improved workplace satisfaction and increased workplace retention among nurse managers working in a hospital in the Phoenix, Arizona area. Terera \& Ngirande (2014) examined the impact of rewards on job satisfaction and employee retention among nurses at a selected health department in the Buffalo City Municipality in Eastern Cape Province of South Africa and found that while employee rewards lead to employee retention, they do not result in job satisfaction.

Findings from most studies suggest that nurses' retention is a factor of affective commitment and satisfaction with both pay and job. Job satisfaction is found to be a strong predictor $(\beta=-0.47, \mathrm{p}=0.001)$ of turnover intentions among Registered Nurses in Samar, Philippines (Labrague, Gloe, McEnroe-Petitte, Tsaras \& Colet, 2018). The influence of affective commitment on the turnover intention of private hospital nurses in Makassar, Indonesia was explored by Guntur, Haerani \& Hasan (2012) with results showing that affective commitment has negative significant effect on nurses' turnover intention. Job satisfaction is reported to directly affect the voluntary nurses job turnover in the health care industry (Cimiotti, Aiken, Sloane $\& \mathrm{Wu}, 2013$ ). If nurses perceive their pay to be competitive, equitable and commensurate, their job satisfying and affective commitment high, research suggest that these factors play very significant role in their turnover intention. Abubakar, et al. (2014) examined the influence of human resource management practices and reported that compensation practices is negatively related to turnover intentions $(\beta=-.12 ; \mathrm{t}=-1.87 ; \mathrm{p}<0.05)$ among Registered Nurses in Nigeria. However, Vandenberghe \& Tremblay (2008) found positive association between pay satisfaction and turnover intention but mediated by affective commitment.

Results from regression analysis (Table 3 ) also indicate that pay satisfaction and job satisfaction have significant positive relationship and explain approximately $35 \%$ of the variance in nurses' affective commitment $\left(r=0.594 ; r^{2}\right.$ $=0.353 ; p<0.05)$ to their hospitals. The effect of job satisfaction on affective commitment among the nurses $(\beta=$ $0.163 ; p<0.007)$ is stronger than the effect of pay satisfaction on their affective commitment $(\beta=0.511 ; p$ $<0.0005$ ) and these are all statistically significant. This implies that nurses' level of satisfaction with their jobs is a significant predictor of their affective commitment to their hospitals. Previous research findings tend to support this result. For instance, Al-Aameri (2000) found a strong positive correlation between job satisfaction and organizational commitment $(0.59, \mathrm{p}<.01)$ among nurses in Saudi public hospitals and A'yuninnsa \& Saptoto (2015) also report that affective commitment was significantly predicted by pay satisfaction $(y 2=.32, p<.05)$. Since pay and job satisfaction are found to be significantly correlated with affective commitment and affective commitment is important for both organizational and employee performance it is important for organizations to ensure that effective policies and practices and developed to make both the job and pay attractive to employees.

Commitment is pivotal to organizational success and often impacts employee attitude and behavior (Klein \& Park, 2016). In particular, affective commitment, defined as "an emotional attachment to the organization such that the strongly committed individual identifies with, is involved in, and enjoys membership within the organization" (Allen \& Meyer, 1990, p. 2) is an important ingredient for organizational stability and sustainability. Researchers have suggested a predictor relationship between affective commitment and intention to stay, extra-role behavior, job satisfaction, high performance and engagement and job satisfaction motivation, performance, pro-social behaviors, well-being, and career success (Meyer, Stanley, Herscovitch, \& Topolnytsky, 2002 in Klein, 2016; Becker, Klein, \& Meyer 2009). This shows the indispensability of employee commitment in relation to organizational success.

The relationship between nurses' pay satisfaction and their satisfaction on the job is significantly positive ( $r=$ 
$0.387 ; r^{2}=0.150 ; p<0.0005$ ) with $15 \%$ explained of the variance in nurses' satisfaction with their jobs. This result is in line with what previous studies which also found significant positive influence of pay satisfaction on job satisfaction (Chan, Leong, Luk, Yeung \& Van, 2010). Lawler (as cited in Shoraj \& Llaci, 2015) suggests that pay satisfaction influences job satisfaction and the Society for Human Resource Management (SHRM, 2017, April 14) identify compensation/pay as a leading factor that contributes to employee job satisfaction. However, a Taiwan Chinese study (Tzeng, 2002) disagrees that salary have strong relationship with job satisfaction. Likewise, Curtis (2007) in a survey of nurses in the Republic of Ireland found that pay make less of a contribution to the current level of job satisfaction. In spite of research results indicating that pay do not predict employee satisfaction with job, it makes business sense for organizations to ensure competitive, commensurate and equitable pay as a strategy to attract and retain talents. A survey of hospital midwives $(n=103)$ and primary-care midwives $(n=405)$ in the Netherlands (Cronie, Perdok, Verhoeven, Jans, Hermus, Vries, \& Rijnders, 2019) found that all midwives were satisfied with their work. However, working hours per week, workplace agreements, and total years of experience were more significant to hospital midwives' job satisfaction while social support at work, work demands, job autonomy, and the influence of work on their private life were most significant to primary care midwives' job satisfaction.

\subsection{Study Limitations}

The scope of this study is limited because only Registered Nurses from Ondo State-owned hospitals are sampled excluding Registered Nurses from Federal Government owned and Private hospitals within the State. This is due to time and financial constraints. However, a cross-sectional study of State, Federal and Private Hospitals would be more robust and generalizable to all types of hospitals. Another limitation is the decision to use convenience sampling which is unlikely to be representative of the entire target population (Fraenkel et al., 2012). The use of quantitative method rather than a mixed method that could have generated better results is also considered to be a limitation. Finally, the survey questions were closed-ended questions that provided limited options ranging from 1 -7 only which probably did not reflect all the intrinsic feelings of the respondents (Spector, 2006). However, for public hospital Registered Nurses with heavy workloads and long working hours, a close-ended survey questionnaire has a higher probability of being completed than an open-ended questionnaire which would require more time to complete.

\section{Conclusion}

On the basis of all results, it could be said that as the levels of job and pay satisfaction reduce among nurses, so do their affective commitment to their organisations reduce which invariably reinforces their intention to quit. The need for Registered Nurses' retention is paramount because of their pivotal role in healthcare delivery, contribution to the success of universal health coverage and sustainable development goals, and the paucity of this stock of healthcare workforce locally and globally. According to a study by El-Jardali et al. (2009), the loss of a Registered Nurse extends the duration of hospitalization by approximately $80 \%$ and the risk of infection by an approximately $20 \%$. An increased nurse turnover may increase the patient to nurse ratio, and lead to increased nursing workload unless further recruitment was possible.

The researchers do not claim that to have identified all the key variables influencing nurse's intention to quit. Affective commitment is related to emotions, organizational identity, and attachment (Allen \& Meyer as cited in Fernandez-Lores, Gavilan, Avello, \& Blasco, 2016) whereas the predictor variables that were considered and also the final outcome variable, i.e. nurses' turnover intentions, are functional in nature. From an operational perspective, it is good to learn that something as intangible as affective commitment could be improved by a sheer tangible variable like the salary paid to nurses. Affective commitment is critically important in turnover intention. Nurses who are not satisfied and lacking affective commitment could still continue to work for a hospital as a result of various extrinsic factors such as the geographic nearness of a hospital to their homes or the lack of other opportunities to work. Even in this case, when they lack emotional commitment, they would not exert their best to their job situations and as a result more negative consequences related to work could occur. Dissatisfied nurses might transmit their negative emotions to their coworkers and patients; in stressful work situations such as during surgical procedures, this might also mean them making wrong decisions leading to greater chances of casualties. Keeping well trained and experienced Registered Nurses may influence lower patient mortality (El-Jardali et al., 2009).

Pay is often considered as a hygiene factor in theories of motivation - meaning, even though pay decreases might cause dissatisfaction, pay increases would not increase satisfaction (McLean, Smits, \& Tanner, 1996). This does not appear to be the case in Nigeria, a developing country. Increasing pay seems to have a positive influence upon nurses' satisfaction and emotional commitment. To enhance Registered Nurses' job satisfaction, affective 
commitment and retention in Ondo State's public hospitals, it is essential to institute competitive, commensurate and equitable pay.

\section{Competing Interests Statement}

The authors declare that there are no competing conflicts of interest.

\section{References}

Akhtar, N., Awan, A. W. A., Anwar, M. A., Saeed, S., Ali, S., \& Qurban, M. (2016). Impact of job satisfaction and remuneration on turnover intention: A survey of private schools of Okara, Pakistan. International Review of Management and Business Research, 5(2), 653-675. Retrieved from www.irmbrjournal.com

Al-Aameri, A. S. (2000). Job satisfaction and organizational commitment for nurses. Saudi Medical Journal, 21(6), 531-535.

Allen, N. J. (2016). Commitment as a multidimensional construct. In J. P. Meyer (Ed.), Handbook of employee commitment (pp. 28-42). Cheltenham, England: Edward Elgar. https://doi.org/10.4337/9781784711740.00012

Allen, N. J., \& Meyer, J. P. (1990). The measurement and antecedents of affective, continuance and normative commitment to the organization. Journal of Occupational Psychology, 63(1), 1-8. https://doi.org/10.1111/j.2044-8325.1990.tb00506.x

Allen, N. J., \& Meyer, J. P. (1991). A three-component conceptualization of organizational commitment. Human Resource Management Review, 1, 61-89. https://doi.org/10.1016/1053-4822(91)90011-Z

Al Maqbali, M. A. (2015). Factors That Influence Nurses' Job Satisfaction: A Literature Review. Nursing Management, 22(2), 30-37. https://doi.org/10.7748/nm.22.2.30.e1297

Asegid, A., Belachew, T., \& Yimam, E. (2014). Factors influencing job satisfaction and anticipated turnover among nurses in Sidama Zone public health facilities, South Ethiopia. Nursing Research and Practice, 909768. https://doi.org/10.1155/2014/909768

A'yuninnisa, R. N., \& Saptoto, R. (2015). The effects of pay satisfaction and affective commitment on turnover intention. International Journal of Research Studies in Psychology, 4. https://doi.org/10.5861/ijrsp.2015.1055

Bahram, H., Hasan, G., Mohammad, H., Hasan, C., \& Alireza, G. (2015). A Survey of nurses' perceptions of the causes of medication errors and barriers to reporting in hospitals affiliated to Neyshabur University of Medical Sciences, Iran. Journal of Kerman University of Medical Sciences, 21(1), 105-111. Retrieved from http://jkmu.kmu.ac.ir/article_16278.html

Barik, S. K., Bramha, S., Behera, D., Bastia, K., Cooper, C., \& Rath, P. (2014). Ecological health assessment of a coastal ecosystem: Case study of the largest brackish water lagoon of Asia. Marine Pollution Bulletin, 138, 352-363. https://doi.org/10.1016/J.marpolbul.2018.11.056

Becker, T. E., Klein, H. J., \& Meyer, J. P. (2009). Commitment in organizations: Accumulated wisdom and new directions. In H. J. Klein, T. E. Becker, \& J. P. Meyer (Eds.), Commitment in organizations: Accumulated wisdom and new directions (pp. 419-452). Routledge/Taylor \& Francis Group.

Blegen, M. A. (1993). Nurses' job satisfaction: A meta-analysis of related variables. Nursing Research, 42(1), 36-41. https://doi.org/10.1097/00006199-199301000-00007

Bolina, A. F., Bomfim, E., \& Lopes-Júnior, L. C. (2020). Frontline nursing care: The COVID-19 pandemic and the Brazillian Health System. SAGE Open Nursing, 6, 2377960820963771. https://doi.org/10.1177/2377960820963771

Bradby, H. (2014). International medical migration: acritical conceptual review of the global movements of doctors and nurses. Health, 18, 580-596. https://doi.org/10.1177/1363459314524803

Buchan, J., \& Aiken, L. (2008). Solving nursing shortages: a common priority. Journal of Clinical Nursing, 17(24). https://doi.org/10.1111/j.1365-2702.2008.02636

Catalyst. (2020). Quick Take: Turnover and Retention (2020, April 16) Retrieved from https://www.catalyst.org/research/turnover-and-retention/

Chan, M. F., Leong, S. M., Luk, A. L., Yeung, S. M., \& Van, I. K. (2010). Exploring the profiles of nurses' job satisfaction in Macau: Results of a cluster analysis. Journal of Clinical Nursing, 19(3-4), 470-478. 
https://doi.org/10.1111/j.1365-2702.2009.02902.x

Chevalier, S., Fouquereau, E., Bénichoux, F., \& Colombat, P. (2019). Beyond working conditions, psychosocial predictors of job satisfaction, and work engagement among French dentists and dental assistants. Journal of Applied Biobehavior Research, 24, e12152. https://doi.org/10.1111/jabr.12152

Chien, W., \& Yick, S. (2016). An investigation of nurses' job satisfaction in a private hospital and its correlates. The Open Nursing Journal, 10, 99-112. https://doi.org/10.2174/1874434601610010099

Christley, R. M. (2016). Questionnaire survey response rates in equine research. Equine Veterinary Journal, 48(2), 138-139. https://doi.org/10.1111/evj.12552

Cimiotti, J. P., Aiken, L. H., Sloane, D. M., \& Wu, E. S. (2013). Nurse staffing, burnout, and healthcare-associated infection. American Journal of Infection Control, 40, 486-490. https://doi.org/10.1016/j.ajic.2012.02.029

CIPD (2021, November). Employee turunover and retention - Learn how to measure turnover and retention, and understand why people leave organisations. Retrieved from https://www.cipd.co.uk/knowledge/strategy/resourcing/turnover-retention-factsheet\#gref

Cohen, G., Blake, R. S., \& Goodman, D. (2015). Does turnover intention matter? Evaluating the usefulness of turnover intention rate as a predictor of actual turnover rate. Review of Public Personnel Administration, 36(3), 240-263. https://doi.org/10.1177/0734371X15581850

Cronie, D., Perdok, H., Verhoeven, C., Jans, S., Hermus, M., de Vries, R., \& Rijnders, M. (2019). Are midwives in the Netherlands satisfied with their jobs? A systematic examination of satisfaction levels among hospital and primary-care midwives in the Netherlands. BMC Health Services Research, 19, 832. https://doi.org/10.1186/s12913-019-4454-x

Dewanto, A., \& Wardhani, V. (2018). Nurse turnover and perceived causes and consequences: a preliminary study at private hospitals in Indonesia. BMC Nursing, 17(2), 52. https://doi.org/10.1186/s12912-018-0317-8

Durokifa, A.A., \& Abdul-Wasi, B.M. (2016). Evaluating Nigeria's Achievement of the Millennium Development Goals (MDGs): Determinants, Deliverables, and shortfalls. Africa's Public Service Delivery \& Performance Review, 4(4). https://doi.org/10.4102/apsdpr.v4i4.147

Eagley, A. H., \& Chaiken, S. (1993). The psychology of attitudes. Fort Worth, TX: Harcourt.

El-Jardali, F., Tchaghchagian, V., \& Jamal, D. (2009). Assessment of human resources management practices in Lebanese hospitals. Human resources for health, 7, 84. https://doi.org/10.1186/1478-4491-7-84

Fernandez-Lores, S., Gavilan, D., Avello, M., \& Blasco, F. (2016). Affective commitment to the employer brand Development and validation of a scale. Business Research Quarterly, 19(1), 40-54. https://doi.org/10.1016/j.brq.2015.06.001

Firth, L., Mellor, D. J., Moore, K. A., \& Loquet, C. (2004). How can managers reduce employee intention to quit? Journal of Managerial Psychology, 19(2), 170-187. https://doi.org/10.1108/02683940410526127

Fraenkel, J. R., Wallen, N. E., \& Hyun, H. H. (2012). How to Design and Evaluate Research in EducatIon (8th ed.). New York: Mc Graw HIll.

Garner, B. R., \& Hunter, B. D. (2014). Predictors of staff turnover and turnover intentions within addiction treatment settings: change over time matters. Substance Abuse: Research and Treatment, 8, SART-S17133. https://doi.org/10.4137/SART.S17133

Goh, Y-S., \& Lopez, V. (2016). Job satisfaction, work environment and intention to leave among migrant nurses working in a publicly funded tertiary hospital. Journal of Nursing Management, 24(7), 893-901. https://doi.org/10.1111/jonm.12395

Greyling, J., \& Stanz, K. (2010). Turnover of nursing employees in a Gauteng hospital group. SA Journal of Industrial Psychology, 30(1), 11. https://doi.org/10.4102/sajip.v36i1.850

Guntur, R. M. Y., Haerani, S., \& Hasan, M. (2012). The influence of affective, continuance and normative commitment on the turnover intentions of nurses at Makassar's private hospitals in Indonesia. African Journal of Business Management, 6(38), 10303-10311. https://doi.org/10.5897/AJBM11.1715

Gutman, P. (2016, June). Tackling trends in turnover. Mercer Webcast Series. Mercer, Frankfurt: Germany. Retrieved from https://www.mercer.com/

Hackman, J. R., \& Lawler, E. E. (1971). Employee reactions to job characteristics. Journal of Applied Psychology, 
55(3), 259-286. https://doi.org/10.1037/h0031152

Haddad, L. M., Annamaraju, P., \& Toney Butler, T. J. (2020). Nursing Shortage. StatPearls. Retrieved from https://www.statpearls.com

Hair, J. J. F., Black, W. C., Rabin, B. J., \& Anderson, R. E. (2014). Multivariate data analysis. Harlow, England: Pearson Education Limited.

Hayes, T. M. (2015). Demographic characteristics predicting employee turnover intentions [Doctoral dissertation, Walden University]. https://scholarworks.waldenu.edu/dissertations/1538

Herzberg, F., Mausner, B., \& Snyderman, B. (1959). The motivation to work (2nd ed.). John Wiley

Hom, P. W., Griffeth, R. W., Palich, L. E., \& Bracker, J. S. (1998). An exploratory investigation into theoretical mechanisms underlying realistic job previews. Personnel Psychology, 51(2), 421-451. https://doi.org/10.1111/j.1744-6570.1998.tb00732.x

Hospitals Management Board Statistics. (2018). May 2018 reports (unpublished).

Hulin, C. L., \& Judge, T. A. (2003). Job attitudes. In W. C. Borman, D. R. Ilgen, \& R. J. Klimoski (Eds.), Handbook of Psychology: Industrial and organizational psychology (Vol. 12, pp. 255-276). John Wiley \& Sons Inc.

Institute for Healthcare Improvement. (2019). Percent of Nurses Voluntary Turnover. Retrieved from http://www.ihi.org/

Iqbal, S., Guohao, L., \& Akhtar, S. (2017). Effects of job organizational culture, benefits, salary on job satisfaction ultimately affecting employee retention. Review of Public Administration and Management, 5, 229. https://doi.org/10.4172/2315-7844.1000229

Kanfer, R. (1990). Motivation theory and industrial and organizational psychology. In M. D. Dunnette \& L. M. Hough (Eds.), Handbook of industrial and organizational psychology (pp. 75-170). Consulting Psychologists Press.

Klein, H. J., \& Park, H. M. (2016). Commitment as a unidimensional construct. In J. P. Meyer (Ed.), Handbook of employee commitment (pp. 28-42). Cheltenham, England: Edward Elgar.

Krejcie, R. V., \& Morgan, D. W. (1970). Determining sample size for research activities. Educational and Psychological Measurement, 30(3), 607-610. https://doi.org/10.1177/001316447003000308

Krueger, P., Brazil, K., Lohfeld, L., Edward, H. G., Lewis, D., \& Tjam, E. (2002). Organization specific predictors of job satisfaction: findings from a Canadian multi-site quality of work life cross-sectional survey. $B M C$ health services research, 2(6). https://doi.org/10.1186/1472-6963-2-6

Labrague, L. J., McEnroe - Petitte, D. M., Tsaras, K., Cruz, J. P., Colet, P. C., \& Gloe, D. S. (2018). Organizational commitment and turnover intention among rural nurses in the Philippines: Implications for nursing management. International Journal of Nursing Sciences, 5(4), 403-408. https://doi.org/10.1016/j.ijnss.2018.09.001

Liu, J. X., Goryakin, Y., Maeda, A. Bruckner, T., \& Scheffler, R. (2017). Erratum to: Global Health Workforce Labor Market Projections for 2030. Human Resource for Health, 15(18). https://doi.org/10.1186/s12960-017-0193-4

Locke, E. A. (1976). The nature and causes of job satisfaction. In M. D. Dunnette (Ed.), Handbook of industrial and organizational psychology (pp. 1297-1349). Chicago: Rand-McNally.

Luna-Arocas, R., \& Lara, F. J. (2020). Talent management, affective organizational commitment and service performance in local government. International Journal of Environmental Research and Public Health, 17(13), 4827. https://doi.org/10.3390/ijerph17134827

McLean, E. R., Smits, S. J., \& Tanner, J. R. (1996). The importance of salary on job and career attitudes of information systems professionals. Information \& Management, 30(6), 291-299. https://doi.org/10.1016/S0378-7206(96)01059-2

MacPhee, M., Dahinten, V. S., \& Havaei, F. (2017). The impact of heavy perceived nurse workloads on patients and Nurse Outcomes. Administrative Sciences, 7(7). https://doi.org/10.3390/admsci7010007

Maslow, A. H. (1943). A theory of human motivation. Psychological Review, 50(4), 370-396. https://doi.org/10.1037/h0054346 
Matlala, D., \& van der Westhuizen, E. 2012. Factors causing nursing turnover at four public hospitals within the Limpopo Sekhukhune District. Administratio Publica, 20(3), 9-25. Retrieved from https://uir.unisa.ac.za/bitstream/handle/

Mavodza, C. (2017). Gender analysis: Sub-Saharan African nurses' migration experiences - a systematic review. (Unpublished Masters Thesis) University of Cape Town, Cape Town, South Africa. Retrieved from http://hdl.handle.net/1142/25456

Mercurio, Z. A. (2015). Affective commitment as a core essence of organizational commitment: An integrative literature review. Human Resource Development Review, 14(4), 389-414. https://doi.org/10.1177/1534484315603612

Meyer, J. P., \& Allen, N. J. (1997). Commitment in the workplace: Theory, research, and application. Sage Publications, Inc.

Morrell, K., Loan-Clarke, J., \& Wilkinson, H. (2004). Organizational Change and Employee Turnover. Personnel Review, 33(2), 161-173. https://doi.org/10.1108/00483480410518022

Naicker, S., Eastwood, J. B., Plange-Rhule, J., \& Tutt, R. C. (2010). Shortage of healthcare workers in sub-Saharan Africa: a nephrological perspective. Clinical Nephrology, 74, S129-33. https://doi.org/10.5414/CNP74S129

National Population Commission. (2006). Population and Housing Census; Priority Table Volume IV, Population Distribution by Age \& Sex (State \& Local Government Area) Table DS5. NPC 2010, Abuja, Federal Republic of Nigeria.

O'Connor, J. (2018). The impact of job satisfaction on the turnover intent of executive level central office administrators in Texas public school districts: A quantitative study of work related constructs. Educational Sciences, 8(69), 1-13. https://doi.org/10.3390/educsci8020069

Oleribe, O. O., \& Taylor-Robinson, S. D. (2016). Before Sustainable Development Goals (SDG): Why Nigeria failed to achieve the Millenium Development Goals (MDGs). Pan African Medical Journal, 24(156). https://doi.org/10.11604/pamj.2016.24.156.8447

Oleribe, O. O., Ezieme, I. P., Oladipo, O., Akinola, E. P., Udofia, D., \& Taylor-Robinson, S. D. (2016). Industrial actions by health workers in Nigeria in 2013-2015: An inquiry into causes, consequences and control-a cross-sectional descriptive study. Human Resource Health, 14(1), 46. https://doi.org/10.1186/s12960-016-0142-7

Ondo State Ministry of Health. (2018). Directorate of nursing services, list of nurses in Ondo State (unpublished).

Pagilagan, H. (2017). Factors that affect turnover intention of registered nurses in the acute hospital: A metaanalysis from 2006-2016 [Doctoral Dissertation, San Jose State University]. SJSU ScholarWorks, 71. https://doi.org/10.31979/etd.xxpf-skw3

Price, J. L. (1977). The study of turnover. Ames: Iowa State Press

Price, J. L., \& Mueller, C. W. (1981). A causal model of turnover for nurses. Academy of Management Journal, 24(3), 543-565. https://doi.org/10.2307/255574

Proctor, S. (2017). Strategies to improve job satisfaction and reduce voluntary employee turnover of nurses [Doctoral Dissertation, Walden University]. ScholarWorks. https://scholarworks.waldenu.edu/dissertations.

Reynolds, N. R. (2020). The year of the nurse and midwife 2020: Activating the potential and power of nursing. Revista Latino-Americana de Enfermagem, 28, e3279. https://doi.org/10.1590/1518-8345.0000-3279

Robbins, S., Judge, T. A., Odendaal, A., \& Roodt, G. (2016). Organisational behaviour: Global and Southern African Perspectives (3rd ed). Prentice-Hall, Johannesburg: South Africa

Saber, D. A. (2014). Frontline registered nurse job satisfaction and predictors over three decades: A meta-analysis from 1980 to 2009. Nursing Outlook, 62, 402-414. https://doi.org/10.1016/j.outlook.2014.05.004

Salami, B., Dada, F. O., \& Adelakun, F. E. (2016). Human resource for health challenges in Nigeria and Nurse Migration. Policy, Politics, \& Nursing Practice, 17(2), 76-84. https://doi.org/10.1177/1527154416656942

Shoraj, D., \& Llaci, S. (2015). Motivation and its impact on organizational effectiveness in Albanian businesses. Sage Open, 5, 1-8. https://doi.org/10.1177/2158244015582229

Silva-flores, R., Pérez-verdín, G., \& Wehenken, C. (2014). Patterns of tree species diversity in relation to climatic 
factors on the Sierra Madre Occidental, Mexico. PLos ONE, 139(5), 10503. https://doi.org/10.1371/journal.pone.0105034.t006

Singh, P., \& Loncar, N. (2010). Pay satisfaction, job satisfaction and turnover intent. Industrial Relations, 65(3), 470. https://doi.org/10.7202/044892ar

Society for Human Resource Management. (2017, April). Employee job satisfaction and engagement: The doors of opportunity are open. Retrieved from https://www.shrm.org/

Sousa-Poza, A., \& Henneberger, F. (2002). An empirical analysis of working-hours constraints in twenty-one countries. Review of social economy, 60(2), 209-242. https://doi.org/10.1080/00346760210146235

Spector, P. E. (1997). Job satisfaction: Application, assessment, causes and consequences. Thousand Oaks, CA, Sage Publications, Inc. https://doi.org/10.4135/9781452231549

Spector, P. E. (2006). Method variance in organizational research: Truth or urban legend? Organizational Research Methods, 9(2), 221-232. https://doi.org/10.1177/1094428105284955

Strafford, F. (2016). Nurse Turnover Rate Infographic. Retrieved from https://www.streamlineverify.com/

Tangcharoensathien, V., Mills, A., \& Palu, T. (2015). Accelerating health equity : the key role of universal health coverage in the Sustainable Development Goals. BMC Medicine, 13(101). https://doi.org/10.1186/s12916-015-0342-3

Terera, S. R., \& Ngirande, H. (2014). The impact of rewards on job satisfaction and employee retention. Mediterranean Journal of Social Sciences, 5(1), 481. https://doi.org/10.5901/mjss.2014.v5n1p481

Tinehealth. (2017, April). The pros and cons of nurse turnover and retention causes and solutions. Retrieved from https://tinehealth.com/

Tshitangano, T. G. (2013). Factors that contribute to public sector nurses' turnover in Limpopo province of South Africa. African Journal of Primary Health Care \& Family Medicine, 5(1), 1-7. https://doi.org/10.4102/phcfm.v5i1.479

Tzeng, H.-M. (2002). The influence of nurses' working motivation and job satisfaction on intention to quit: an empirical investigation in Taiwan. International Journal of Nursing Studies, 39(8), 867-878. https://doi.org/10.1016/S0020-7489(02)00027-5

Vandenberghe, C., \& Tremblay, M. (2008). The role of pay satisfaction and organizational commitment in turnover intentions: A two-sample study. Journal of Business and Psychology, 22(3), 275-286. https://doi.org/10.1007/s10869-008-9063-3

WHO, Africa. (2017, August). What needs to be done to solve the shortage of health workers in the African Region. Retrieved from https://www.afro.who.int/news/what-needs-be-done-solve-shortage-health-workers-africanregion

Yeager, V. A., \& Wisniewski, J. M. (2017). Factors that influence the recruitment and retention of nurses in public health agencies. Public Health Reports, 132(5), 556-562. https://doi.org/10.1177/0033354917719704

Yilmazel, G. (2013). Mobbing, job satisfaction and affecting factors in the nurse. Turkiye Clinic Journal of Nursing Science, 5(2), 55-63.

\section{Copyrights}

Copyright for this article is retained by the author(s), with first publication rights granted to the journal.

This is an open-access article distributed under the terms and conditions of the Creative Commons Attribution license (http://creativecommons.org/licenses/by/4.0/). 